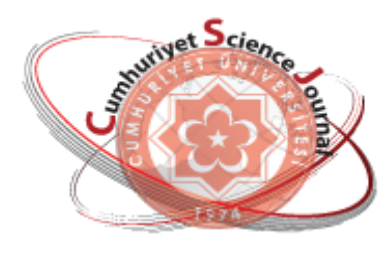

e-ISSN: $2587-246 X$

ISSN: $2587-2680$

\section{Cuculaniy ot Seionce Journal $\operatorname{csg}$}

Cumhuriyet Sci. J., Vol.40-1(2019) 245-252

\title{
A Geographical Information System (GIS) Based Traceability System Suggestion for a Pastry Firm Operating Nationwide
}

\author{
Evren GÖLGE ${ }^{1 *(1)}$, Tarık TÜRK ${ }^{2}$ (iD) \\ ${ }^{1}$ Sivas Cumhuriyet University, Food Engineering Department, Sivas, TURKEY \\ ${ }^{2}$ Sivas Cumhuriyet University, Engineering Faculty, Geomatics Engineering Department, Sivas, TURKEY
}

Received: 11.12.2017; Accepted: 28.01.2019

http://dx.doi.org/10.17776/csj.352607

\begin{abstract}
Logistics and traceability are important issues for big scale firms. Traceability is primarily viewed as a tool for the food safety by providing a mean for recall as well as proof for the authenticity of food, but it is also related to food quality. Maintaining the cold chain not only effecting the customer's preference and satisfaction but also the profitability, production and logistic costs for big scale firms especially producing perishable food products. Recently, the trend of utilizing GIS based traceability systems is increasing, which facilitates to minimize the production and distribution of unsafe and low quality food products. This paper presents a GIS based system enabling network analysis, which might be efficiently and effectively used in the firms operating in ready-to-eat pastry sector, intended to be used for full-automation through all the stages from production to retail was developed and a partial application was performed.
\end{abstract}

Keywords: GIS, Traceability, Food Safety.

\section{Ulusal Çapta Faaliyet Gösteren Tatlı Firması için Coğrafi Bilgi Sistemi (CBS) Tabanlı İzleme Sistemi Önerisi}

Özet. Lojistik ve izlenebilirlik büyük ölçekli firmalar için önemli konulardır. İzlenebilirlik öncelikle gıda güvenliği için gıdaların orijinalliğini ispatlamanın yanı sıra geri çağırma olanaklarını da sağlayan bir araç olarak görülmekle birlikte gıda kalitesiyle de doğrudan ilgilidir. Soğuk zincir sadece müssterilerin tercih ve memnuniyetini etkilemekle kalmayıp özellikle bozulabilir gıda ürünleri üreten büyük ölçekli firmaların kârlılık, üretim ve lojistik giderlerini de etkilemektedir. Son zamanlarda, CBS tabanlı izlenebilirlik sistemlerini kullanma eğilimi giderek artmakta ve bu da düşük kaliteli gıda ürünlerinin üretimini ve dağıtımını en aza indirmeyi kolaylaştırmaktadır. Bu çalışmada, üretimden perakendeye kadar tüm aşamalarda tam otomasyona yönelik hazır pasta ve tatlı sektöründe faaliyet gösteren firmalarda etkili ve etkin bir şekilde kullanılabilecek ăg analizinin kullanıldığı CBS tabanlı bir sistem geliştirilerek kısmi bir uygulama yapılmıştır.

Anahtar Kelimeler: CBS, İzlenebilirlik, Gıda Güvenliği.

\section{INTRODUCTION}

Food products require cautious and strategic handling procedures because they have a short life span. Food-borne illnesses and microbiological contamination can easily occur if food is improperly handled during production, storage, or distribution. The food industry is continuously susceptible to the outbreak of illnesses such as Salmonella, Campylobacter and Escherichia coli O157:H7, etc. Outbreaks focus consumer concern on the safety and quality of food $[1,2]$.

In national and international food companies and the global food trade, food chain integrity concerns 
safety as well as origin fraud and quality concerns. It appears to be a great problem for many firms to ensure the integrity of the cold chain as well as address customer preferences and satisfaction in addition to profitability, production, and logistic costs, especially for perishable food products managed by large companies. Consumers demand verifiable evidence of traceability to ensure food quality and safety. To respond to these demands, a traceability system is needed that provides information on the origin, processing, retailing, and final destination of foodstuffs.

In general terms, quality can be defined as "conformance to requirement" or "fitness for use or consumption". According to the ISO definition, "quality is the totality of features and characteristics of a product that bear on its ability to satisfy stated or implied needs" [3]. However, food quality is very general, implying that expectations of individual consumers may differ dramatically. Quality includes attributes that influence a product's value to the consumer. A product can appear to be of high quality (i.e. wellcoloured, appetizing, and flavourful, etc.), but it can be unsafe because of undetected pathogenic organisms, toxic chemicals, or physical hazards [4]. The CAC (2003) defines food safety as an assurance that food will not cause harm to the consumer when it is prepared and/or eaten according to its intended use [5]. Food safety refers to all hazards, whether chronic or acute, that may make food injurious to the health of the consumer. It is a non-negotiable, global issue affecting billions of people who suffer from diseases caused by contaminated food. In ensuring food safety, Hazard Assurance Critical Control Point (HACCP) is regarded as the best method. In addition, it is the best way to demonstrate commitment to food safety [6].

Effective logistics management requires delivering the right product, in the right quantity, in the right condition, to the right place, at the right time, and for the right cost [7]. Logistics greatly affect profit, price, and the consumer satisfaction, so logistics management is important to the success of food producers [8]. In the process of improving logistics, detailed location analysis (mapping and clustering of raw material suppliers, production and retail sites, etc.) and route analysis (creating optimal routes for product collection and distribution, simulating route distance and delivery time) are essential.

According to ISO 9000 (2005) standards, traceability is defined as: "the ability to trace the history, application or location of that which is under consideration". ISO guidelines further specify that traceability may refer to the origin of materials and parts, the processing history, or the distribution and location of the product after delivery. The European Union (EU) regulation 178/2002 [9] narrows the definition to the food industry by defining traceability as the ability to trace and follow a food, feed, food-producing animal or substance intended to be, or expected to be incorporated into a food or feed, through all stages of production, processing, and distribution. The Codex Alimentarious Commission [5] defines a more concise definition of traceability as the ability to follow the movement of a food through specified stages of production, processing, and distribution.

According to Golan et al. (2004) the three main objectives of food traceability systems are 1) to improve supply management, 2) to facilitate backtracing for food safety and quality, and 3) to differentiate and market foods with subtle or undetectable quality attributes [10]. The benefits of these objectives appear as lower-cost distribution systems, reduced recall expenses, and expanded sales of products with attributes that are difficult to discern. It was also suggested that an efficient traceability system should be characterized by breadth (i.e. the amount of information collected), time depth (i.e. tracking information forward and backward in time) and precision (i.e. degree of assurance to pinpoint a particular movement of a food product in order to evaluate costs and benefits).

Consumers are increasingly concerned about food safety and the properties of the food they buy and eat. It has been recognized that there is an increasing need for transparent information on the 
quality of the entire food chain supported by modern tracing methods [11, 12]. Moe (1998) mentioned that traceability is an essential subsystem of quality management [13]. A welldeveloped internal traceability system would improve data collection efficiency, production flow control, and quality assurance.

Geographical Information Systems (GIS) are information systems that can integrate geographical data during data acquisition, storage, processing, inquiry, analysis, and certification steps. It is used in many areas including the food sector [14-18].

This study's objective is to propose a GIS-based control system for efficient and safe product transportation for ready-to-eat desserts in Turkey.
For this reason, a nationwide firm that excels in various milk and dough desserts was selected as a case study.

\section{MATERIALS AND METHODS}

The national company STP Gıda A.Ş. has been chosen for the proposed GIS based system in this study. It has four production facilities (two in İstanbul, one in İzmir and one in Ankara) and 190 retail outlets [19]. The total number of outlets and their locations are presented in Table 1. The firm has the most outlets in the Marmara and Aegean regions and the fewest in the Eastern and South Eastern Anatolia regions. This is quite understandable because the company is based in the Aegean region, which is also where its highestcapacity production facility is located.

Table 1. The location of the firm's subsidiaries.

\begin{tabular}{|c|c|c|c|c|c|c|c|c|c|c|c|}
\hline \multirow{2}{*}{$\begin{array}{l}\text { Region } \\
\text { Marmara }\end{array}$} & \multicolumn{9}{|c|}{ Provinces and the number of the retail outlets } & \multirow{2}{*}{$\begin{array}{l}\text { of retail } \\
\text { outlets }\end{array}$} & \multirow[t]{2}{*}{ Percent } \\
\hline & Bursa & Çanakkale & İstanbul & Kırklareli & Kocaeli & Tekirdağ & & & & & \\
\hline & 5 & 2 & 48 & 1 & 3 & 2 & & & & 61 & 32,1 \\
\hline \multirow[t]{2}{*}{ Aegean } & Afyon & Aydın & Balıkesir & Denizli & İzmir & Manisa & Muğla & Uşak & & & \\
\hline & $\begin{array}{c}2 \\
\text { Aksaray }\end{array}$ & $\begin{array}{c}5 \\
\text { Ankara }\end{array}$ & $\begin{array}{c}3 \\
\text { Eskisehir }\end{array}$ & $\begin{array}{c}3 \\
\text { Kayseri }\end{array}$ & $\begin{array}{c}28 \\
\text { Kırıkkale }\end{array}$ & $\begin{array}{c}1 \\
\text { Kırşehir }\end{array}$ & $\begin{array}{c}4 \\
\text { Konya }\end{array}$ & $\begin{array}{c}1 \\
\text { Niğde }\end{array}$ & Sivas & 47 & 24,7 \\
\hline Central Anatolia & 1 & 13 & 1 & 3 & 1 & 1 & 3 & 1 & 1 & 25 & 13,2 \\
\hline \multirow[t]{2}{*}{ Mediterranean } & Adana & Antakya & Antalya & Isparta & Mersin & Osmaniye & & & & & \\
\hline & 3 & 1 & 9 & 2 & 2 & 1 & 18 & & & 36 & 18,9 \\
\hline \multirow[t]{2}{*}{ Black Sea } & Bolu & Düzce & Ordu & Samsun & Sinop & Tokat & Trabzon & Zonguldak & & & \\
\hline & 1 & 1 & 1 & 4 & 1 & 1 & 1 & 2 & & 12 & 6,3 \\
\hline \multirow[t]{2}{*}{ South Eastern Anatolia } & Batman & Diyarbakır & Gaziantep & Mardin & Şanlıurfa & & & & & & \\
\hline & 1 & 1 & 1 & 1 & 1 & & & & & 5 & 2,6 \\
\hline \multirow[t]{2}{*}{ Eastern Anatolia } & Elazığ & Erzurum & Malatya & Van & & & & & & & \\
\hline & 1 & 1 & 1 & 1 & & & & & & 4 & 2,1 \\
\hline & & & & & & & & & & 190 & 100 \\
\hline
\end{tabular}

The whole range of products produced by the firm both milk and dough type of desserts have been selected as the material of the study. The product names are listed in Fig. 1 under the title "Product Sell Number". Milk desserts constitute the great portion of the products of the firm. Apparently, milk products are perishable type of foods. Parallel to the scope of this study, these type of products must be swiftly transported to subsidiaries and customers following their production. From this point of view the strategies in the process of product delivery followed by the firm are strictly critical for the profitability and hence implicating a great risk.

In creation of the proposed GIS based system, the first step was the random formation of the retail data of each 190 retail outlets of the firm. The daily retail data for each product in each retail outlet of the firm was randomly formed between 1 to 100 retails daily for 365 days through three consecutive years (2013-2015) by random data generation function of the Excel programme in Microsoft Office Professional Plus.

A GIS based system was established considering all the steps in the transportation of each of the products produced by the firm. In this system both geographical and non-geographical data exist. While creating the system, the firm's product tree were formed first. Then, the geographical locations of the subsidiaries were transferred the created system by detecting on the satellite view and on the map considering the data exist on the website of the 
firm. Turkey's transportation web and province border data was used as exist geographical data (Fig. 1).

On the other hand, a database including the parameters for the retail of the products of the firm and the cold chain was designed (Fig. 1). This database was integrated in ArcGIS10.1 GIS software environment. Besides a user-interface program was developed to facilitate the interaction between the software and the user that enables the utilization of the software without requiring software background [20, 21]. In result, the user can reach and query the desired data for all the production facilities and subsidiaries of the firm in which retail process occur (Fig. 1 and Fig. 2).

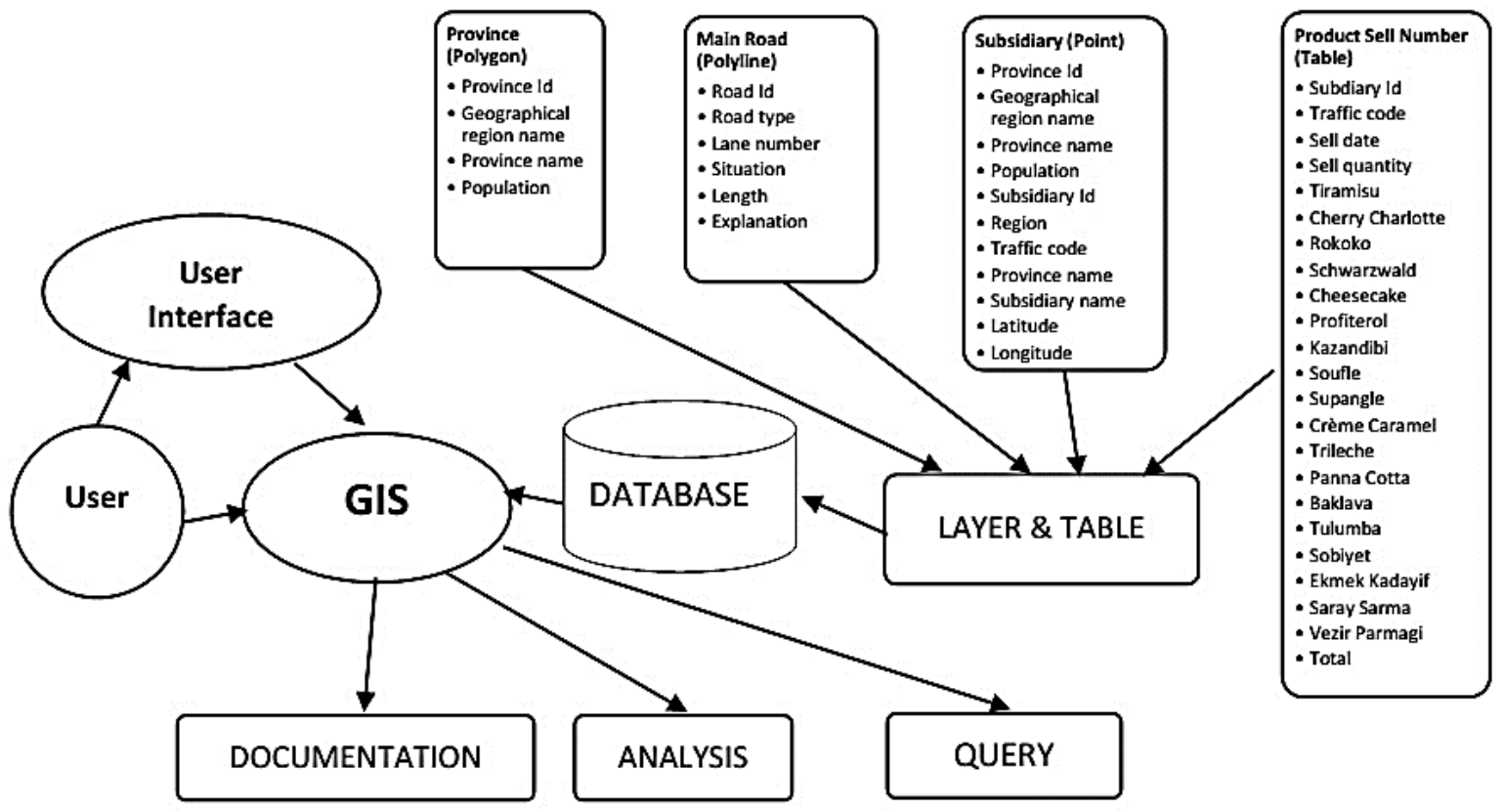

Figure 1. Schematic description of the created system.

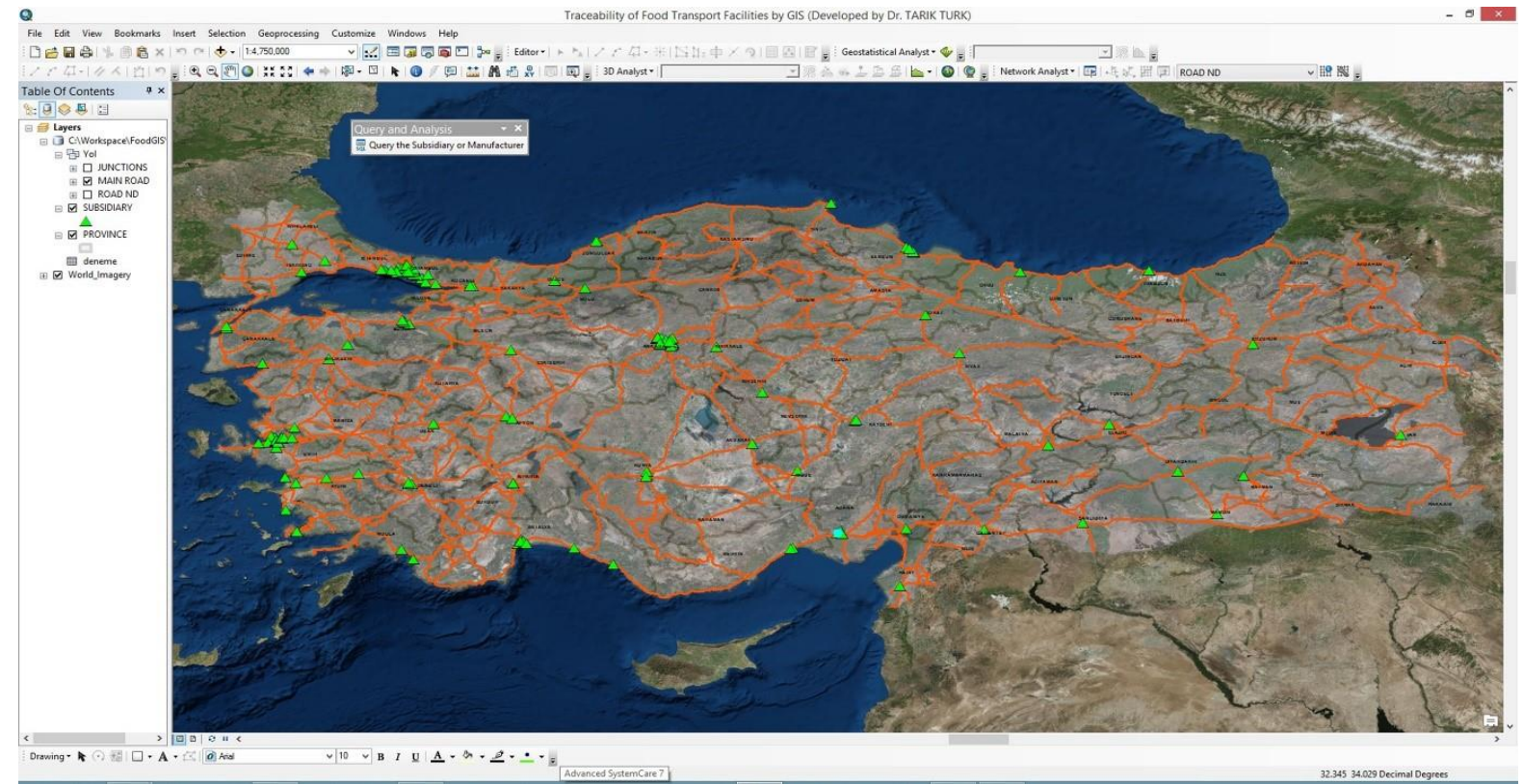

Figure 2. General view of the created system and user interface program developed on ArcGIS Software environment. 


\section{RESULTS AND DISCUSSION}

In this study, a GIS based system established aiming to maintain full automation of the operations from production stage to retail stage in subsidiaries of a selected nationwide operating model firm in ready-to-eat pastry sector in Turkey. The capability of the established system was as follows:

- Monitoring by a GIS based system,

- Accessing the geographical location and the detailed information of the production sites and the subsidiaries of the firm (Fig . 2 and 3),

- Requirement of the new production sites or subsidiaries in the strategic planning of the firm, and if necessary with the help of geographical analysis (Buffer Analysis, Density Analysis, Clustering Analysis, Network Analysis etc.) the determination of the geographical location of the new production site to be installed,

- Determination of retail statistics of any product type produced by the firm with respect to subsidiaries and profitability of any subsidiary with one click (Fig. 3),

- Selection of the production site for any random subsidiary to be supplied from (Fig. 4)

The difference and originality of the system proposed in this paper from similar previous systems could be listed as many operations executed by the firm are GIS based and performed with the help of the user interface program developed in the frame of this study [14, 22]. Besides the retail statistics of the firm's products can be obtained with one click through the created system (Fig. 3). In addition a wide perspective was presented for the profitability of the firms operating in this sector by performing Network Analysis applications in a GIS based system.

As the firm is operating nationwide, the 4 production facilities and 190 subsidiaries have been dispersed all over Turkey. The locations of each 4 production facilities and each 190 subsidiaries have been shown on the map of the created system using ArcGIS10.1 software (Fig. 2). With the help of these programs not only the statistical data on the product retail of the firm but also the geographical locations of the subsidiaries on the map could be selected and all the data on the selected subsidiary is obtainable with one click (Fig. 3).

In this paper it is not possible to present most of the query and geographical analysis that could be accessed provided by the system. For this reason some of these were presented in the following scenarios.

\section{Scenario 1}

In this scenario, all the retail information of the selected product type "Tiramisu" for the subsidiary selected "Adana Real" can be queried on day, month and annual basis with one click by the user interface program developed (Fig. 3).

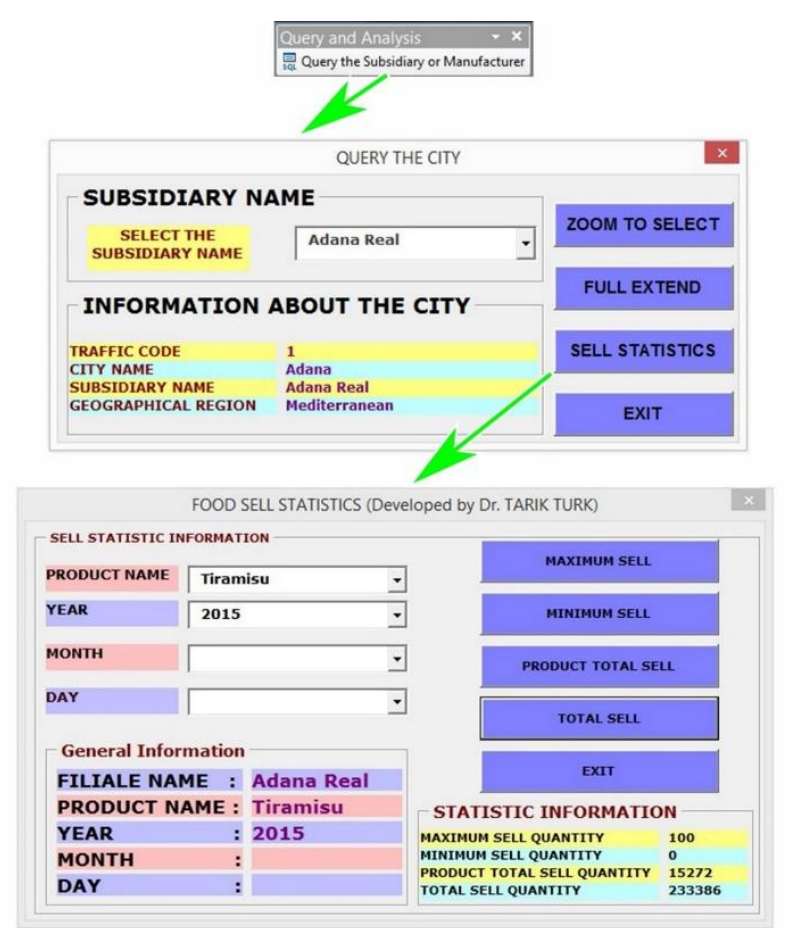

Figure 3. The user interface programs developed. 


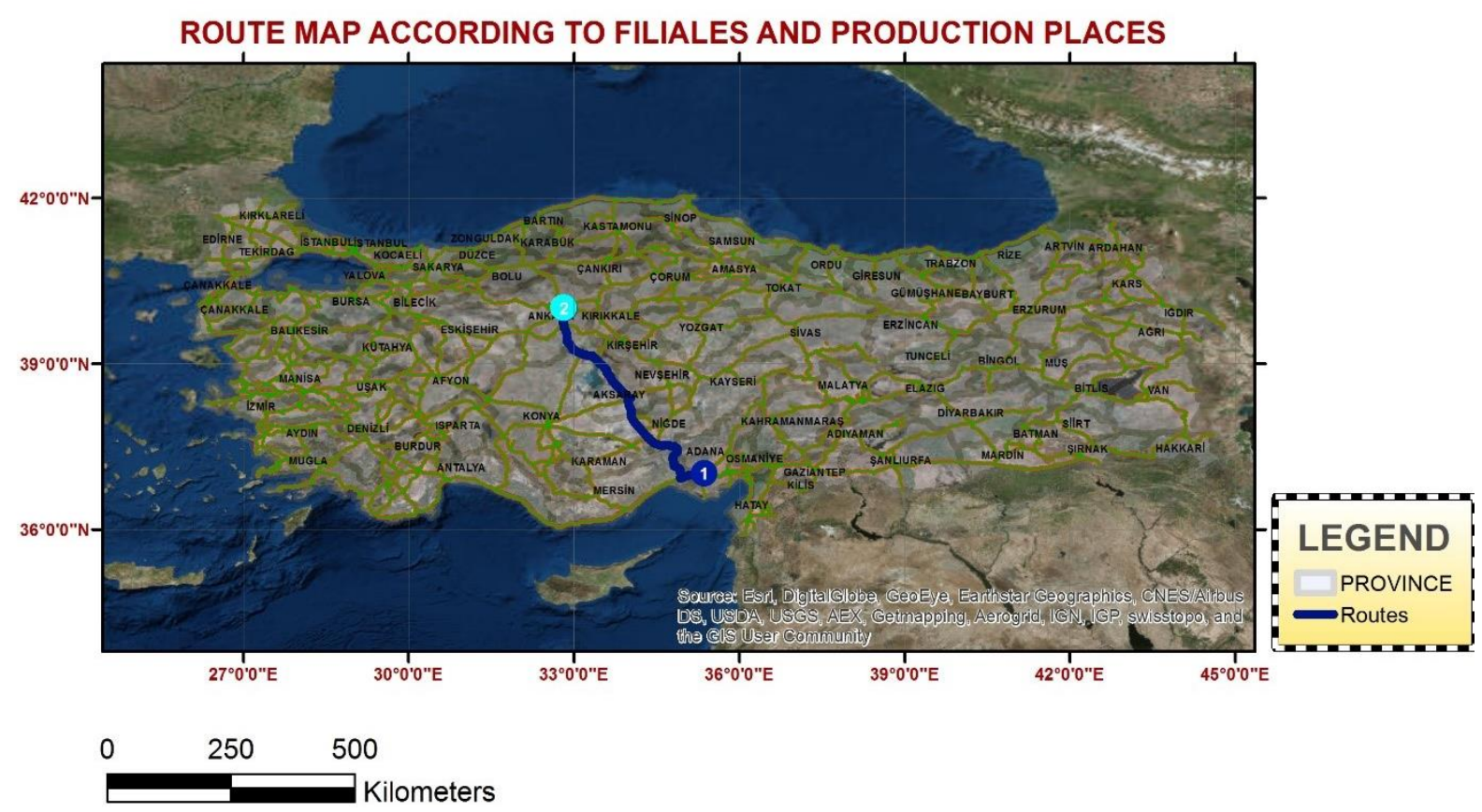

Figure 4. Route map according to the subsidiaries and production places.

Alongside the optimum route determination, regarding to the position of the subsidiary and the effective utilization of the sources, the address matching and resource allocation and similar applications of network analysis the production, retail and logistic activities of the firm can be executed swiftly, effectively and efficiently. In addition, with the help of buffer analysis or network service area analysis the location of the newly formed production sites could be determined by the established GIS based system.

\section{CONCLUSIONS}

A GIS based system, which might be efficiently and effectively used in the firms operating in readyto-eat pastry sector, intended to be used for fullautomation through all the processes from production stage to retail stage was developed and a partial application was performed within the scope of this study. Thus, all the activities of the firm was stored in a geographical database and all kind of information is instantly reachable by inquiry. Furthermore, differing from the classical database in addition to geographical analysis operations, the implemented system can answer geographical based questions such as, considering the costs from which present production site the product must be transported to the retail subsidiaries as well as the determination and optimization of the geographical site of the potently established production sites. By this means the implemented system have a potential to increase the profit of the firms and facilitates the delicate products of the ready-to-eat pastry sector be transported safely to consumers situated far away.

Product-tracing systems are essential for food safety and quality control. Traceability systems help firms isolate the source and extent of safety or quality control problems. The more precise the tracing system, the faster a producer can identify and resolve food safety or quality problems. Quality and safety are both linked to traceability whereas safety is implicated by traceability more often.

Traceability is primarily viewed as a tool for the food safety by providing a means for recall as well as proof for the authenticity of food, but it is also related to food quality. Since both quality and safety were shown to be related to confidence, traceability may indeed boost consumer confidence through quality and safety assessments. 
Cold chain is a critical issue for food sector. It has direct and indirect effects on human health, company profitability, etc. In the present study the system was designed both considering the production and expiry date and time of the product. As if the production and expiry data for each product would have been entered into the database and the vehicle tracking and navigation systems would have been integrated with the system established, the process from production stage to final user could be easily tracked on real-time basis.

On the other hand, different from the other systems presented in literature, when the desired retail prices of the products are set to the established system, the retail revenues of each individual subsidiary could be calculated on daily, monthly and annual basis for each different product type.

In result GIS based control systems certainly help a food firm especially operating with perishable products in resource allocation, route optimization, product traceability, etc. As the technology develops with the use of sophisticated sensors (e.g. RFID technology, nanosensors), the control parameters of the food product will increase which directly effects the level of real-time monitoring and efficiency of the GIS control systems. Thus, food safety management will be promoted and gain much more flexibility and accuracy.

\section{Acknowledgements}

This study was presented in $4^{\text {th }}$ Geobalcanica Conference (Ohrid, Republic of Macedonia 15-16 May 2018).

\section{REFERENCES}

[1] Bertolini M., Bevilacqua M., Massini R. Approach To Product Traceability In The Food Industry. Food Control, 17 (2006) 137145.

[2] Trienekens J., Zuurbier P. Quality And Safety Standards In The Food Industry, Developments And Challenges. International Journal Of Production Economics, 113-1 (2008) 107-122.

[3] Guidelines for quality management in soil and plant laboratories.

Address:
http://www.fao.org/3/W7295E/W7295E00.ht m. Retrieved July 2, 2017.

[4] Safety and quality of fresh fruit and vegetables: A training manual for trainers. United Nations. Address: https://unctad.org/en/docs/ditccom200616_en .pdf. Retrieved July 24, 2017.

[5] Codex Alimentarius Commission. Basic Texts On Food Hygiene. Address: http://www.fao.org/docrep/012/a1552e/a1552 e00.htm. Retrieved September 25, 2017.

[6] International Organization for Standardization. ISO 22000 Food Safety Management. Address: https://www.iso.org/obp/ui/\#iso:std:iso:2200 0:ed-2:v1:en. Retrieved September 25, 2017.

[7] Aghazadeh, S. Improving Logistics Operations Across The Food Industry Supply Chain. International Journal of Contemporary Hospitality Management, 16-4 (2004) 263268.

[8] Brimer R.C. Logistics Networking: A Consideration Of The Components Essential To An Integrated Logistics Support Network. Logistics Information Management 8-4 (1995) 8-11.

[9] EU. Regulation (EC) No 178/2002 Of The European Parliament And Of The Council. Address: https://www.ecolex.org/details/legislation/reg ulation-ec-no-1782002-of-the-europeanparliament-and-of-the-council-laying-downthe-general-principles-and-requirements-offood-law-establishing-the-european-foodsafety-authority-and-laying-downprocedures-in-matters-of-food-safety-lexfaoc034771/. Retrieved September 25, 2017.

[10] Golan E., Krissoff B., Kuchler F., Calvin L., Nelson K., Price G. Traceability In The U.S. Food Supply: Economic Theory And Industrial Studies. Agricultural Economic Report. Address: https://ageconsearch.umn.edu/bitstream/3393 9/1/ae040830.pdf. Retrieved September 20, 2017.

[11] Beulens A.J. M., Broens D.F., Folstar P., \& Hofstede, G. J. Food Safety And 
Transparency In Food Chains And Networks. Food Control, 16-6 (2005) 481-486.

[12] Rijswijk W.V., Frewer L.J. How Consumers Link Traceability To Food Quality And Safety: An International Investigation. Address:

http://ageconsearch.umn.edu/bitstream/10061 /1/sp06va02.pdf. Retrieved September 22, 2017.

[13] Moe T. Perspectives On Traceability In Food Manufacture. Trends In Food Science \& Technology, 9-5 (1998) 211-214.

[14] Bosona T., Gebresenbet G. Cluster Building And Logistics Network Integration Of Local Food Supply Chain. Biosystems Engineering, 108 (2011) 293-302.

[15] Bosona T., Gebresenbet G. Food Traceability As An Integral Part Of Logistics Management In Food And Agricultural Supply Chain. Food Control, 33 (2013) 32-48.

[16] Eckert J., Shetty S. Food Systems, Planning and Quantifying Access: Using GIS To Plan For Food Retail. Applied Geography, 31 (2011) 1216-1223.

[17] Mcmeekin T.A., Baranyi J., Bowman J., Dalgaard P., Kirk M., Ross T., Schmid S., Zwietering, M.H. Information Systems In Food Safety Management. International
Journal Of Food Microbiology, 112 (2006) 181-194.

[18] Suprem A., Mahalik N., Kim K. A Review On Application Of Technology Systems, Standards And Interfaces For Agriculture And Food Sector. Computer Standards \& Interfaces, 35 (2013) 355-364.

[19] Özsüt Company Website. Address: http://en.ozsut.com.tr/. Retrieved September $1,2015$.

[20] Turk T., Gumusay U., Tatar O. Creating Infrastructure For Seismic Microzonation By Geographical Information Systems (GIS): A Case Study In The North Anatolian Fault Zone (NAFZ). Computers \& Geosciences, 43 (2012) 167-176.

[21] Turk T. Investigating Health Studies Using Geographical Information Systems: Cancer Case Study. Polish Journal Of Environmental Studies, 22-5 (2013) 1505-1517.

[22] Hashemi Beni L., Villeneuve S., Leblanc D.I., Côté K., Fazil A., Otten A., Mckellar R., Delaquis P. Spatio-Temporal Assessment Of Food Safety Risks In Canadian Food Distribution Systems Using GIS. Spatial And Spatio-Temporal Epidemiology, 3 (2012) 215-223. 